
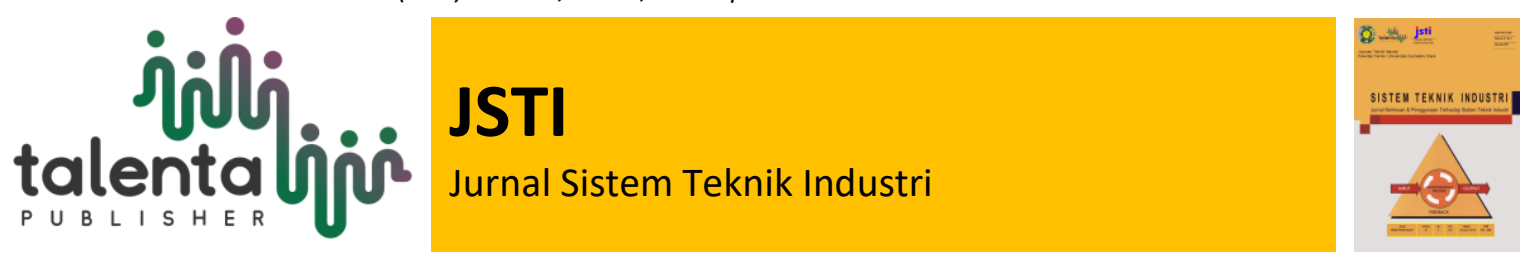

\title{
Perbandingan Tingkat Stres Mahasiswa Empat Angkatan Program Studi Teknik Industri dengan Metode Skoring dari Health and Safety Executive
}

\author{
Nana Rahdiana \\ Program Studi Teknik Industri, Fakultas Teknik dan Ilmu Komputer, Universitas Buana Perjuangan \\ Karawang
}

\begin{abstract}
Stres dapat diartikan sebagai tekanan psikologis yang dapat menimbulkan penyakit baik fisik maupun mental. Stres pada mahasiswa dapat berupa rasa cemas atau tegang yang terjadi dalam perkuliahan, pengerjaan tugas dan kegiatan akademik lainnya. Stres dapat mempengaruhi mahasiswa dalam menyelesaikan studinya. Penelitian ini bertujuan untuk mengetahui perbedaan tingkat stres antara mahasiswa angkatan 2015, 2016, 2017 dan 2018 Program Studi Teknik Industri, Universitas Buana Perjuangan Karawang pada tahun 2019. Metode penelitian ini merupakan penelitian analitik observasional dengan pendekatan cross sectional. Data diperoleh dengan membagikan kuesioner kepada 90 responden mahasiswa yang dibagi secara proporsional tiap angkatan dengan mengikuti rumus Slovin.Teknik pengambilan sampel yang digunakan simple random sampling. Penelitian ini menggunakan instrumen kuesioner HSE, data dianalisis statistik dengan Indendent T-test dan Anova, serta uji korelasi dengan metode Point-biserial Correlation dari Pearson dan Spearmen's Rho.

Dari hasil penelitian ini terdapat perbedaan tingkat stres antara mahasiswa angkatan 2015, 2016, 2017 dan 2018, dimana mahasiswa angkatan 2015 cenderung stres rendah sebesar 50,0\%, sementara angkatan 2016, 2017, dan 2018 cenderung stres sedang dengan persentase berturut-turut $55,6 \% ; 65,4 \%$; dan $64,7 \%$. Jenis kelamin, usia dan status kerja mahasiswa tidak mempengaruhi tingkat stres, serta tidak memiliki hubungan yang berarti dengan tingkat stres.
\end{abstract}

Keyword: Mahasiswa, HSE, Uji Korelasi, Tingkat Stres

Abstrak. Stress can be interpreted as psychological pressure that can cause both physical
and mental illness. Stress on students can be anxious or tense that occurs in lectures, work
assignments and other academic activities. Stress can influence students in completing their
studies. This study aims to determine differences in stress levels between students in 2015 ,
2016,2017 and 2018 Industrial Engineering Study Program, University of Buana
Perjuangan Karawang in 2019. This research method is an observational analytic study
with approach cross sectional. Data was obtained by distributing questionnaires to 90
student respondents who were divided proportionally per class by following the Slovin
formula used was sampling technique simple random sampling. The. This study used the HSE
questionnaire instrument, the data were analyzed statistically with the Independent T-test
and Anova, as well as the correlation test with the method Point-biserial Correlation from
Pearson and Spearmen's Rho. From the results of this study there are differences in stress
levels between students in 2015, 2016, 2017 and 2018 , where students in 2015 tend to be low
stressed by 50.0\%, while the classes of 2016,2017 and 2018 tend to be moderate stress with

*Corresponding author at: Universitas Buana Perjuangan Karawang, Jawa Barat, Indonesia

E-mail address: nana.rahdiana@ubpkarawang.ac.id 
a percentage of 55,6\%; 65.4\%; and 64.7\%. Sex, age and work status of students do not affect stress levels, and do not have a significant relationship with stress levels.

Kata Kunci: Student, HSE, Correlation Test, Stress Level

Received 10 Desember 2019 | Revised 20 Januari 2020 | Accepted 25 Januari 2020

\section{Pendahuluan}

Proses perkuliahan, bukan hanya sekedar datang ke kampus, hadir di kelas, ikut serta dalam ujian, dan lulus. Aktualnya tidak sesederhana itu, begitu banyak aktivitas yang dilaksanakan selama proses perkuliahan, baik yang berupa kegiatan akademik maupun non akademik. Mahasiswa diharapkan mampu memahami kondisi yang ada, dimana saat ini mereka berada pada level pendidikan paling tinggi, kondisinya jauh berbeda dengan saat berada di Sekolah Lanjutan Tingkat Atas (SLTA). Menurut Handono dan Basori, 2013 (dalam jurnal Maulina dan Sari, 2018) "Kegagalan individu dalam melakukan penyesuaian diri dalam bidang pendidikan dapat menyebabkan individu mengalami gangguan psikologis, salah satunya merasakan stres". Lingkungan Perguruan Tinggi membuat mahasiswa baru mengalami perubahan dan menuntut mereka untuk melakukan penyesuaian terhadap lingkungan baru tersebut. Tuntutan ini dapat menimbulkan permasalahan, yaitu dapat membuat mahasiswa menjadi stres.

Menurut Jogaratnam dan Buchanan 2004 , Stres mahasiswa atau stres akademik adalah tekanan mental dan emosional yang terjadi akibat tuntutan di lingkungan kampus. Sumber stres akademik meliputi: suasana yang membosankan, suasana bising, proses belajar yang monoton, tugas yang menumpuk, kurang komunikasi, merasa tidak dihargai, aturan yang membingungkan, pelayanan akademik yang tidak memuaskan, biaya kuliah yang tinggi, dan lain-lain.

Tingkat drop out yang tinggi, menjadi alasan peneliti untuk melakukan penelitian, yaitu pengukuran tingkat stres mahasiswa. Penelitian mengambil sampel mahasiswa Teknik Industri, Universitas Buana Perjuangan Karawang (TI UBP Karawang) dari 4 (empat) angkatan yaitu 2015, 2016, 2017 dan 2018, pengukuran dilakukan pada semester genap tahun akademik 2018/2019.

Hasil observasi sementara menunjukan bahwa mahasiswa TI UBP Karawang memiliki keluhan, diataranya: bosan dengan pertemuan yang monoton, tugas kuliah yang terlalu banyak, kehadiran dosen, mata kuliah yang dipadatkan pertemuannya, materi yang sulit dipahami, sering pusing, tidak nafsu makan, sulit tidur, sering merasa cemas, dan mudah tersinggung.

\section{Latar Belakang}

Beberapa penelitian telah dilakukan untuk menilai tingkat stres di kalangan mahasiswa, diantaranya: (1). Mahasiswa tahun pertama dan tahun kedua kenderung memiliki tingkat stres yang tinggi dibandingkan dengan mahasiswa tahun lainnya [1] ; (2). Derajat stres mahasiswa tahun pertama lebih tinggi jika dibandingkan dengan mahasiswa tahun kedua, ketiga, dan keempat [2] ; (3). Terdapat perbedaan tingkat stres yang signifikan dimana tingkat stres mahasiswa tahun pertama lebih berat daripada tingkat stres mahasiswa tahun kedua dan seterusnya. Sedangkan tidak ada perbedaan signifikan antara tingkat stres dengan karakteristik usia, jenis kelamin, asal sekolah dan jalur masuk [8] ; (4). Tingkat stres mahasiswa tingkat awal lebih tinggi dibandingkan tingkat stres mahasiswa pada tingkat akhir [3].

Hasil penelitian terhadap mahasiswa reguler Fakultas Ilmu Keperawatan (FIK), Universitas Indonesia angkatan 2010 menunjukan bahwa semakin tinggi tingkatan usia, maka cenderun akan 
mengalami penurunan tingkat stres, tidak terdapat perbedaan yang signifikan tingkat stres akademik antara laki-laki dan perempuan, dan tingkat stres akademik tidak bergantung pada prestasi mahasiswa [4].

\section{Metodologi}

Metode penelitian yang dipakai adalah metode deskriptif analitik dengan pendekatan cross sectional (studi potong lintang), yaitu mengumpulkan atau mengambil data pada waktu tertentu [5]. Sampel penelitian terdiri dari 90 orang mahasiswa Teknik Industri dari 4 (empat) angkatan, yaitu: 2015, 2016, 2017 dan 2018 yang dihitung dengan rumus Slovin dan dibagi secara proporsional untuk jumlah sampel tiap-tiap angkatannya.

Rumus Slovin dipakai untuk menghitung ukuran sampel minimum (n) pada suatu ukuran populasi (N). Jika $\mathrm{N}=900$ dan tingkat signifikansi $\alpha(10 \%)$, maka $\mathrm{n}$ adalah:

$$
\mathrm{n}=\frac{N}{1+N \alpha^{2}} \quad=\frac{900}{1+900(0,1)^{2}}=90 \text { sampel }
$$

Sehingga perhitungan ukuran sampel tiap-tiap angkatannya dapat dilihat pada tabel berikut:

Tabel 1 Ukuran sample pengukuran tingkat stres

\begin{tabular}{cccccc}
\hline Angkatan & $\begin{array}{c}\text { Jumlah } \\
\text { Mahasiswa }\end{array}$ & Prosentase & \multicolumn{3}{c}{$\begin{array}{c}\text { Ukuran Sample } \\
\text { Slovin }\end{array}$} \\
\hline 2015 & 120 & $13 \%$ & 11,7 & $\approx$ & 12 \\
2016 & 180 & $20 \%$ & 18,0 & $\approx$ & 18 \\
2017 & 260 & $29 \%$ & 26,1 & $\approx$ & 26 \\
2018 & 340 & $38 \%$ & 34,2 & $\approx$ & 34 \\
\hline TOTAL & $\mathbf{9 0 0}$ & $\mathbf{1 0 0 \%}$ & & & $\mathbf{9 0}$ \\
\hline
\end{tabular}

\subsection{Tahap Penelitian}

Tahap-tahap penelitian yang dilakukan adalah:

\section{Tahap ke-1}

Pada tahap ke-1 dilakukan pendalaman studi literatur. Tahap ini dilakukan untuk mempelajari beberapa hasil penelitian sebelumnya. Hasil dari tahap ini berupa model atau desain penelitian yang akan digunakan.

\section{Tahap ke-2}

Pada tahap ke-2 dilakukan penentuan sampel dan instrumen penelitian. Hasil yang diharapkan adalah sebuah instrumen penelitian yang valid dan reliabel.

\section{Tahap ke-3}

Pada tahap ke-3 dilakukan tabulasi data (rekap data) yang selanjutnya dilakukan pengolahan data dengan uji statistik, hasilnya berupa uji validasi.

\section{Tahap ke-4}

Pada tahap ke-4 dilakukan penyusunan laporan penelitian dengan target luaran berupa publikasi pada jurnal atau pertemuan ilmiah nasional [6].

Secara lengkap, tahapan-tahapan penelitian tersebut diatas dapat dilihat pada Gambar 1 . 


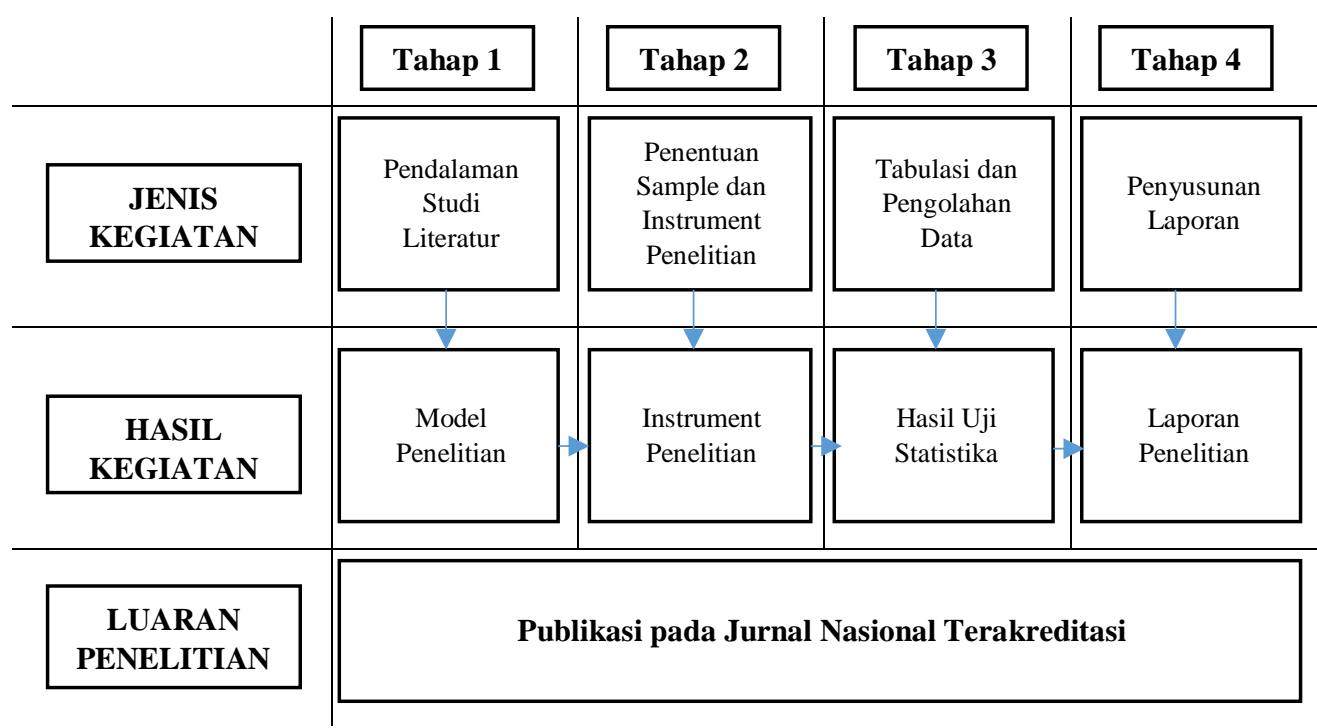

Gambar 1 Tahapan kegiatan penelitian

\subsection{Populasi dan Ukuran Sampel}

Populasi penelitian adalah mahasiswa aktif pada tahun akademik 2018/2019. Jumlah populasi yang tercatat 900 mahasiswa untuk 4 (empat) angkatan, yaitu: 2015, 2016, 2017, dan 2018. Dengan menggunakan rumus Solvin diperoleh ukuran sampel sebanyak 90 mahasiswa yang dibagi secara proporsional untuk setiap angkatannya. Margin of error yang digunakan sebesar 10\%. Pengambilan sampel dilakukan secara random [7] .

\subsection{Pengumpulan Data}

Data yang dipakai pada penelitian ini adalah data primer. Data diperoleh dengan menggunakan kuesioner kepada mahasiswa sebagai responden. Kuesioner dibagi dalam dua bagian. Bagian pertama berupa data demografi responden (nama, jenis kelamin, usia, angkatan, dan status mahasiswa yang bekerja dan tidak bekerja). Bagian kedua berupa pernyataan-pernyataan yang menggambarkan keadaan stres pada seseorang. Penelitian ini diukur menggunakan kuesioner Heath and Safety Executive (HSE-2003), menggunakan desain penilaian dengan skoring (5 skala likert) dari 35 pertanyaan yang diajukan. Pernyataan keadaan stres yang terdapat pada HSE 2003 dilakukan modifikasi, sehingga bisa menggambarkan keadaan dari objek penelitian.

\subsection{Pengujian Alat Ukur}

Kualitas data yang dihasilkan dapat dievaluasi dengan uji validitas dan uji reliabilitas. Uji validitas dilakukan untuk memastikan bahwa alat ukur yang dipakai sesuai dengan konsep dan tujuan penelitian. Uji reliabilitas dilakukan untuk mengindikasi tingkat konsistensi hasil pengukuran pada gejala-gejala yang sama dengan alat ukur yang sama [8].

\subsection{Analisis Data}

Analisis data dilakukan berdasarkan kategori. Variabel yang dipakai dalam penelitian ini adalah tingkat stres. Variabel stres akan dikategorikan kedalam beberapa kategori tingkat stres, yaitu: stres rendah, stres sedang, stres tinggi, dan stres sangat tinggi, atau dengan kata lain (stress ringan, sedang, berat, dan sangat berat).

Analisis univariat dipakai untuk mendeskripsikan data hasil pengukuran. Data demografi responden seperti: jenis kelamin, usia, angkatan dan status bekerja/ tidak bekerja dianalisis secara kategori, yaitu memakai distibusi frekuensi dan disajikan dalam bentuk presentase. 
Analisis bivariat menggunakan uji beda dari variabel tingkat stres dengan beberapa sub variabel, seperti: jenis kelamin, usia, angkatan, dan status bekerja/ tidak bekerja. Uji beda menggunakan beberapa metode, tergantung dari skala sub variabel yang dibandingkan. Tabel 2 dibawah ini menunjukan metode-metode uji beda yang dipakai pada penelitian ini [9] .

Tabel 2 Metode uji beda

\begin{tabular}{lll}
\hline Variabel Independent & Variabel Dependent & Metode Uji Beda \\
\hline Jenis Kelamin & Tingkat Stres & Independent T-Test \\
Usia & Tingkat Stres & Independent T-Test \\
Angkatan & Tingkat Stres & Anova \\
Status Kerja & Tingkat Stres & Independent T-Test \\
\hline
\end{tabular}

Metode Independent T-test ini dipakai untuk membandingkan tingkat signifikansi beda ratarata dua kelompok. Selain itu, uji ini juga dapat dipakai untuk menguji pengaruh variabel independent (seperti: jenis kelamin, usia, dan status kerja (bekerja/tidak bekerja)) terhadap variabel dependent. Sedangkan metode One Way ANOVA atau ANOVA, adalah metode komparatif yang dapat dipakai untuk membandingkan beberapa variabel independent (angkatan 2015, 2016, 2017 dan 2018) dengan satu variabel dependent (tingkat stres).

Tahap selanjutnya adalah melakukan uji korelasi (hubungan). Dalam penelitian ini uji korelasi dilakukan untuk menjawab keempat hipotesis yang dirumuskan. Metode yang dipakai dalam uji korelasi ditetapkan berdasarkan variabel yang akan dihubungkan. Metode uji korelasi yang dipakai dalam penelitian ini dapat dilihat pada tabel 3.

Tabel 3 Metode uji korelasi

\begin{tabular}{lll}
\hline Variabel Independent & Variabel Dependent & Metode Uji Korelasi \\
\hline Jenis Kelamin & Tingkat Stres & Point Biserial Correlation \\
Usia & Tingkat Stres & Point Biserial Correlation \\
Angkatan & Tingkat Stres & Spearmen's Rho \\
Status Kerja & Tingkat Stres & Point Biserial Correlation \\
\hline
\end{tabular}

Metode Spearmen's Rho untuk untuk uji korelasi dua variabel yang salah satu variabelnya memiliki skala pengukuran ordinal. Sedangkan metode Point Biserial Correlation sangat baik dipakai untuk mencari hubungan dua variabel yang salah satu variabelnya memiliki skala pengukuran nominal. Metode Point Biserial Correlation juga dipakai untuk variabel yang memiliki skala pengukuran nominal yang memiliki sifat diskrit bukan kontinyu. Jika variabel skala pengukuran nominal bersifat kontinyu, maka metode uji yang dipakai adalah Biserial Correlation.

\section{Result and Discussion}

\subsection{Data Penelitian}

Data demografi responden berdasarkan: jenis kelamin, usia, angkatan, dan status bekerja atau tidak bekerja dapat dilihat pada tabel 4 sampai dengan tabel 7. Pengolahan data dengan menggunakan SPSS Statistics 19. 
Tabel 4 Data responden berdasarkan jenis kelamin

\begin{tabular}{llrrrr}
\hline & & & & \multicolumn{2}{c}{$\begin{array}{c}\text { Cumulative } \\
\text { Percent }\end{array}$} \\
\hline \multirow{2}{*}{ Valid } & Lakequency & Percent & Valid Percent & 64,4 \\
& Perempuan & 58 & 64,4 & 64,4 & 100,0 \\
& Total & 32 & 35,6 & 35,6 & \\
\hline
\end{tabular}

Dari data tersebut dapat disimpulkan bahwa sebagian besar mahasiswa yang menjadi responden berjenis kelamin laki-laki yaitu sebesar $64,4 \%$.

Tabel 5 Data responden berdasarkan usia

\begin{tabular}{lrrrrr}
\hline & & & & \multicolumn{2}{c}{$\begin{array}{c}\text { Cumulative } \\
\text { Percent }\end{array}$} \\
\hline Valid & $<25$ & 61 & 67,8 & 67,8 & 67,8 \\
& $>=25$ & 29 & 32,2 & 32,2 & 100,0 \\
& Total & $\mathbf{9 0}$ & $\mathbf{1 0 0 . 0}$ & $\mathbf{1 0 0 . 0}$ & \\
\hline
\end{tabular}

Dari data tersebut dapat disimpulkan bahwa responden didominasi oleh mahasiswa yang berusia dibawah 25 tahun, dengan persentase sebesar 67,8\%.

Tabel 6 Data responden berdasarkan angkatan

\begin{tabular}{ll|r|r|r|r}
\hline & \multicolumn{1}{c}{ Frequency } & \multicolumn{1}{c}{ Percent } & \multicolumn{1}{c}{ Valid Percent } & \multicolumn{1}{c}{ Percent } \\
\hline Valid & 2015 & 12 & 13,3 & 13,3 & 13,3 \\
& 2016 & 18 & 20,0 & 20,0 & 33,3 \\
2017 & 26 & 28,9 & 28,9 & 62,2 \\
& 2018 & 34 & 37,8 & 37,8 & 100,0 \\
& Total & $\mathbf{9 0}$ & $\mathbf{1 0 0 , 0}$ & $\mathbf{1 0 0 , 0}$ & \\
\hline
\end{tabular}

Ukuran sampel terbesar adalah mahasiswa angkatan 2018 yaitu sebesar $37,8 \%$.

Tabel 7 Data responden berdasarkan status kerja

\begin{tabular}{llrrrr}
\hline & & & & \multicolumn{2}{c}{ Cumulative } \\
& & Frequency & Percent & Valid Percent & \multicolumn{1}{c}{ Percent } \\
\hline Valid & Bekerja & 46 & 51,1 & 51,1 & 51,1 \\
& Tidak Bekerja & 44 & 48,9 & 48,9 & 100,0 \\
& Total & $\mathbf{9 0}$ & $\mathbf{1 0 0 , 0}$ & $\mathbf{1 0 0 , 0}$ & \\
\hline
\end{tabular}

Dari data tersebut terlihat penyebaran responden berdasarkan status kerja, yakni: sebanyak $51,1 \%$ adalah mahasiswa yang kuliah sambil bekerja, dan sisanya sebanyak $48,9 \%$ adalah mahasiswa yang kuliah tidak sambil bekerja dengan kata lain adalah mahasiswa regular.

\subsection{Pengolahan Data}

Pengolahan data dilakukan dalam bentuk uji validitas dan uji reliabilitas, konversi data, dan uji korelasi (hubungan) dari variabel-variabel yang digunakan dalam penelitian.

Uji validitas yang digunakan pada penelitian ini dengan metode "korelasi item-total", metode yang dipakai adalah metode korelasi pearson yang hasil tampak pada tabel 8 , berikut dibawah ini: 
Tabel 8 Hasil pengujian validitas metode Pearson

\begin{tabular}{|c|c|c|c|c|}
\hline & $\begin{array}{c}\text { Scale Mean if Item } \\
\text { Deleted }\end{array}$ & $\begin{array}{l}\text { Scale Variance if } \\
\text { Item Deleted }\end{array}$ & $\begin{array}{l}\text { Corrected Item- } \\
\text { Total Correlation }\end{array}$ & $\begin{array}{c}\text { Cronbach's Alpha if } \\
\text { Item Deleted }\end{array}$ \\
\hline $\mathrm{P} 1$ & 120,71 & 265,893 & 0,438 & 0,904 \\
\hline $\mathrm{P} 2$ & 120,52 & 268,500 & 0,326 & 0,906 \\
\hline P3 & 120,76 & 268,322 & 0,370 & 0,905 \\
\hline $\mathrm{P} 4$ & 120,44 & 265,081 & 0,429 & 0,905 \\
\hline P5 & 119,91 & 266,621 & 0,371 & 0,905 \\
\hline P6 & 120,48 & 268,342 & 0,343 & 0,906 \\
\hline P7 & 120,33 & 260,742 & 0,593 & 0,902 \\
\hline P8 & 120,53 & 264,454 & 0,521 & 0,903 \\
\hline P9 & 121,49 & 267,219 & 0,384 & 0,905 \\
\hline P10 & 120,83 & 262,140 & 0,552 & 0,903 \\
\hline P11 & 120,39 & 258,555 & 0,594 & 0,902 \\
\hline $\mathrm{P} 12$ & 120,57 & 268,585 & 0,335 & 0,906 \\
\hline P13 & 120,54 & 264,813 & 0,440 & 0,904 \\
\hline P14 & 120,38 & 269,294 & 0,313 & 0,906 \\
\hline $\mathrm{P} 15$ & 120,34 & 258,925 & 0,604 & 0,902 \\
\hline P16 & 121,18 & 265,519 & 0,406 & 0,905 \\
\hline P17 & 120,60 & 262,917 & 0,572 & 0,903 \\
\hline P18 & 120,67 & 268,629 & 0,363 & 0,905 \\
\hline P19 & 120,37 & 259,628 & 0,578 & 0,902 \\
\hline P20 & 120,94 & 269,356 & 0,308 & 0,906 \\
\hline $\mathrm{P} 21$ & 120,03 & 268,752 & 0,340 & 0,906 \\
\hline P22 & 120,44 & 266,632 & 0,407 & 0,905 \\
\hline $\mathrm{P} 23$ & 121,23 & 267,080 & 0,357 & 0,906 \\
\hline $\mathrm{P} 24$ & 120,87 & 259,263 & 0,620 & 0,902 \\
\hline $\mathrm{P} 25$ & 120,79 & 261,112 & 0,581 & 0,902 \\
\hline P26 & 120,57 & 264,181 & 0,442 & 0,904 \\
\hline P27 & 120,43 & 257,574 & 0,631 & 0,901 \\
\hline P28 & 120,98 & 262,224 & 0,487 & 0,904 \\
\hline P29 & 120,56 & 264,362 & 0,499 & 0,904 \\
\hline P30 & 119,88 & 269,749 & 0,336 & 0,906 \\
\hline P31 & 120,54 & 268,745 & 0,362 & 0,905 \\
\hline P32 & 121,16 & 267,863 & 0,397 & 0,905 \\
\hline P33 & 120,39 & 263,004 & 0,536 & 0,903 \\
\hline P34 & 120,40 & 266,782 & 0,371 & 0,905 \\
\hline $\mathrm{P} 35$ & 121,03 & 268,392 & 0,319 & 0,906 \\
\hline
\end{tabular}

Berdasarkan uji validitas yang dijelaskan pada tabel diatas diperoleh nilai korelasi Pearson untuk setiap pertanyaan (P1-P35) terhadap skor total indikator (korelasi item-total) memiliki nilai diatas 0,30 yaitu menunjukkan hasil yang signifikan. Dapat disimpulkan semua pertanyaan atau indikator yang dipakai pada kuesioner adalah valid.

Uji reliabilitas yang dipakai menggunakan nilai Cronbach Alpha. Hasil uji reliabilitas berupa nilai Cronbach Alpha, dapat dilihat pada tabel 9.

Tabel 9 Hasil pengujian reliabilitas Cronbach's Alpha

\begin{tabular}{ll}
\hline Cronbach's Alpha & N of Items \\
\hline 0,907 & 35 \\
\hline
\end{tabular}

Dari tabel diatas diketahui nilai Cronbach Alpha sebesar 0,907 dapat disimpulkan bahwa kuesioner yang dipakai adalah sangat erat (sangat reliable). Konversi data digunakan untuk mengukur tingkat stres responden. Pada penelitian ini alat ukur yang dipakai adalah kuesioner Hearth and Safety Executive [10], menggunakan desain penilaian dengan skoring (5 skala likert) dari 35 pertanyaan yang diajukan. 
Tabel 10 Hasil perhitungan tingkat stres

\begin{tabular}{|c|c|c|c|c|c|}
\hline & & Frequency & Percent & Valid Percent & Cumulative Percent \\
\hline \multirow[t]{47}{*}{ Valid } & 92 & 2 & 2,2 & 2,2 & 2,2 \\
\hline & 98 & 2 & 2,2 & 2,2 & 4,4 \\
\hline & 99 & 2 & 2,2 & 2,2 & 6,7 \\
\hline & 100 & 2 & 2,2 & 2,2 & 8,9 \\
\hline & 101 & 2 & 2,2 & 2,2 & 11,1 \\
\hline & 102 & 2 & 2,2 & 2,2 & 13,3 \\
\hline & 103 & 2 & 2,2 & 2,2 & 15,6 \\
\hline & 104 & 2 & 2,2 & 2,2 & 17,8 \\
\hline & 106 & 2 & 2,2 & 2,2 & 20,0 \\
\hline & 108 & 2 & 2,2 & 2,2 & 22,2 \\
\hline & 109 & 1 & 1,1 & 1,1 & 23,3 \\
\hline & 112 & 2 & 2,2 & 2,2 & 25,6 \\
\hline & 113 & 2 & 2,2 & 2,2 & 27,8 \\
\hline & 115 & 3 & 3,3 & 3,3 & 31,1 \\
\hline & 116 & 1 & 1,1 & 1,1 & 32,2 \\
\hline & 117 & 4 & 4,4 & 4,4 & 36,7 \\
\hline & 118 & 1 & 1,1 & 1,1 & 37,8 \\
\hline & 119 & 2 & 2,2 & 2,2 & 40,0 \\
\hline & 120 & 2 & 2,2 & 2,2 & 42,2 \\
\hline & 121 & 2 & 2,2 & 2,2 & 44,4 \\
\hline & 123 & 3 & 3,3 & 3,3 & 47,8 \\
\hline & 124 & 3 & 3,3 & 3,3 & 51,1 \\
\hline & 125 & 3 & 3,3 & 3,3 & 54,4 \\
\hline & 126 & 1 & 1,1 & 1,1 & 55,6 \\
\hline & 128 & 4 & 4,4 & 4,4 & 60,0 \\
\hline & 129 & 3 & 3,3 & 3,3 & 63,3 \\
\hline & 130 & 1 & 1,1 & 1,1 & 64,4 \\
\hline & 131 & 2 & 2,2 & 2,2 & 66,7 \\
\hline & 132 & 3 & 3,3 & 3,3 & 70,0 \\
\hline & 133 & 1 & 1,1 & 1,1 & 71,1 \\
\hline & 135 & 2 & 2,2 & 2,2 & 73,3 \\
\hline & 136 & 1 & 1,1 & 1,1 & 74,4 \\
\hline & 137 & 2 & 2,2 & 2,2 & 76,7 \\
\hline & 138 & 1 & 1,1 & 1,1 & 77,8 \\
\hline & 141 & 3 & 3,3 & 3,3 & 81,1 \\
\hline & 142 & 1 & 1,1 & 1,1 & 82,2 \\
\hline & 143 & 3 & 3,3 & 3,3 & 85,6 \\
\hline & 144 & 3 & 3,3 & 3,3 & 88,9 \\
\hline & 145 & 1 & 1,1 & 1,1 & 90,0 \\
\hline & 146 & 2 & 2,2 & 2,2 & 92,2 \\
\hline & 149 & 2 & 2,2 & 2,2 & 94,4 \\
\hline & 152 & 1 & 1,1 & 1,1 & 95,6 \\
\hline & 153 & 1 & 1,1 & 1,1 & 96,7 \\
\hline & 154 & 1 & 1,1 & 1,1 & 97,8 \\
\hline & 160 & 1 & 1,1 & 1,1 & 98,9 \\
\hline & 162 & 1 & 1,1 & 1,1 & 100,0 \\
\hline & Total & 90 & 100,0 & 100,0 & \\
\hline
\end{tabular}

Tabel 11. Jumlah responden berdasarkan tingkat stres

\begin{tabular}{cccccc}
\hline Tingkat Stres & $\begin{array}{c}\text { Tingkat Risiko } \\
\text { Stres }\end{array}$ & Jumlah & Presentase & $\begin{array}{c}\text { Persentase } \\
\text { Kumulatif }\end{array}$ & Kategori Stres \\
\hline $105-139$ & 0 & 20 & 22,2 & 22,2 & Rendah \\
$140-175$ & 1 & 54 & 60,0 & 82,2 & Sedang \\
$70-104$ & 2 & 16 & 17,8 & 100,0 & Tinggi \\
$35-69$ & 3 & 0 & 0 & 100,0 & Sangat Tinggi \\
\hline
\end{tabular}

Berdasarkan pengelompokan data pada tabel diatas diketahui bahwa sebagian besar responden berada pada tingkat stres rendah, yaitu sebesar $22,2 \%$, berikutnya tingkat stres sedang sebesar $60,0 \%$, dan tingkat stres tinggi sebesar 17,8\%. Dari data tersebut tidak ada mahasiswa atau responden yang memiliki tingkat stres sangat tinggi. 
Sementara jika data sebaran stres tersebut kita kategorikan beradasarkan jenis kelamin, usia, angkatan, dan status kerja dari responden, maka hasilnya dapat dilihat pada tabel 12, sebagai berikut:

Tabel 12 Persentase tingkat stres berdasarkan kategori responden

\begin{tabular}{lllllll}
\hline Kategori & & Rendah & Sedang & Tinggi & $\begin{array}{c}\text { Sangat } \\
\text { Tinggi }\end{array}$ & Total \\
\hline Jenis Kelamin & Laki-laki & $19,0 \%$ & $63,8 \%$ & $17,2 \%$ & $0 \%$ & $100,0 \%$ \\
& Perempuan & $28,1 \%$ & $53,1 \%$ & $18,8 \%$ & $0 \%$ & $100,0 \%$ \\
\multirow{2}{*}{ Usia } & & & & & & \\
& $>=25$ & $24,6 \%$ & $54,1 \%$ & $21,3 \%$ & $0,0 \%$ & $100,0 \%$ \\
\multirow{2}{*}{ Angkatan } & 2015 & $17,2 \%$ & $72,4 \%$ & $10,3 \%$ & $0,0 \%$ & $100,0 \%$ \\
& 2016 & $50,0 \%$ & $41,7 \%$ & $8,3 \%$ & $0,0 \%$ & $100,0 \%$ \\
& 2017 & $11,1 \%$ & $55,6 \%$ & $33,3 \%$ & $0,0 \%$ & $100,0 \%$ \\
& 2018 & $23,1 \%$ & $65,4 \%$ & $11,5 \%$ & $0,0 \%$ & $100,0 \%$ \\
\multirow{2}{*}{ Status Kerja } & $17,6 \%$ & $64,7 \%$ & $17,6 \%$ & $0,0 \%$ & $100,0 \%$ \\
& Bekerja & $21,7 \%$ & $65,2 \%$ & $13,0 \%$ & $0,0 \%$ & $100,0 \%$ \\
& Tidak Bekerja & $22,7 \%$ & $54,5 \%$ & $22,7 \%$ & $0,0 \%$ & $100,0 \%$ \\
\hline
\end{tabular}

Sebelum uji korelasi (hubungan) dilaksanakan, terlebih dahulu lakukan uji beda. Uji beda dilakukan untuk mengetahui apakah variabel tingkat stres berbeda dengan beberapa variabel yang lain, seperti: jenis kelamin, usia, tahun angkatan, dan status kerja dari mahasiswa.

Tabel 13 Uji beda stres dan jenis kelamin

\begin{tabular}{|c|c|c|c|c|c|c|c|c|c|c|}
\hline & \multicolumn{2}{|c|}{$\begin{array}{l}\text { Levene's Test for } \\
\text { Equality of } \\
\text { Variances }\end{array}$} & \multicolumn{4}{|c|}{ t-test for Equality of Means } & \multirow[b]{2}{*}{$\begin{array}{l}\text { Std, } \\
\text { Error } \\
\text { Differe } \\
\text { nce }\end{array}$} & \multirow{2}{*}{\multicolumn{2}{|c|}{$\begin{array}{l}95 \% \text { Confidence } \\
\text { Interval of the } \\
\text { Difference } \\
\text { Lower Upper }\end{array}$}} \\
\hline & & $\mathrm{F}$ & Sig, & $\mathrm{t}$ & $\mathrm{df}$ & $\begin{array}{l}\text { Sig, } \\
(2- \\
\text { tailed })\end{array}$ & $\begin{array}{l}\text { Mean } \\
\text { Differe } \\
\text { nce }\end{array}$ & & & \\
\hline \multirow[t]{2}{*}{$\begin{array}{l}\text { Skor } \\
\text { Individu }\end{array}$} & $\begin{array}{l}\text { Equal variances } \\
\text { assumed }\end{array}$ & 0,083 & 0,774 & $-0,669$ & 88 & 0,505 & $-2,474$ & 3,697 & $-9,822$ & 4,874 \\
\hline & $\begin{array}{l}\text { Equal variances } \\
\text { not assumed }\end{array}$ & & & $-0,654$ & 59,990 & 0,515 & $-2,474$ & 3,781 & $-10,037$ & 5,089 \\
\hline
\end{tabular}

Dilihat dari data diatas nilai signifikansi antara stres dan jenis kelamin adalah 0,505 (lebih besar dari 0,05). Hasil uji beda dar penelitian ini menunjukan bahwa tingkat stres mahasiswa TI UBP Karawang tidak berbeda untuk laki-laki dan perempuan.

Tabel 14 Uji beda stres dan usia

\begin{tabular}{|c|c|c|c|c|c|c|c|c|c|c|}
\hline & $\begin{array}{l}\text { Leven } \\
\text { Equali } \\
\text { Varian }\end{array}$ & Test fo & $t$-test fo & Equalit & $\mathrm{y}$ of Mea & & & & \\
\hline & & $\mathrm{F}$ & Sig, & $\mathrm{t}$ & df & $\begin{array}{l}\text { Sig, } \\
(2- \\
\text { tailed) }\end{array}$ & $\begin{array}{l}\text { Mean } \\
\text { Differe } \\
\text { nce }\end{array}$ & $\begin{array}{l}\text { Std, } \\
\text { Error } \\
\text { Differe } \\
\text { nce }\end{array}$ & $\begin{array}{l}95 \% \\
\text { Interval } \\
\text { Difference } \\
\text { Lower }\end{array}$ & $\begin{array}{l}\text { Confidence } \\
\text { of the } \\
\text { ce } \\
\text { Upper }\end{array}$ \\
\hline \multirow[t]{2}{*}{$\begin{array}{l}\text { Skor } \\
\text { Individu }\end{array}$} & $\begin{array}{l}\text { Equal variances } \\
\text { assumed }\end{array}$ & 0,982 & 0,324 & $-0,114$ & 88 & 0,910 & $-0,432$ & 3,797 & $-7,977$ & 7,113 \\
\hline & $\begin{array}{l}\text { Equal variances } \\
\text { not assumed }\end{array}$ & & & $-0,120$ & $\begin{array}{l}63,57 \\
2\end{array}$ & 0,905 & $-0,432$ & 3,593 & $-7,610$ & 6,746 \\
\hline
\end{tabular}

Dapat dilihat bahwa nilai signifikansi antara stres dan usia adalah 0,910 (lebih besar dari 0,05), dengan demikian dapat disimpulkan bahwa tingkat stres mahasiswa TI UBP Karawang tidak ada perbedaan karena faktor usia. 
Tabel 15 Uji beda stres dan angkatan kuliah

\begin{tabular}{|c|c|c|c|c|c|}
\hline & Sum of Squares & df & Mean Square & $\mathbf{F}$ & Sig, \\
\hline Between Groups & $2.287,596$ & 3 & 762,532 & 2,895 & 0,040 \\
\hline Within Groups & $22.648,226$ & 86 & 263,351 & & \\
\hline Total & $24.935,822$ & 89 & & & \\
\hline
\end{tabular}

Dapat dilihat bahwa nilai F hitungnya adalah 2,895 (lebih besar daripada nilai $\mathrm{F}$ tabel = 2,76), maka Ho ditolak atau $\mathrm{H} 1$ diterima yaitu terdapat perbedaan tingkat stres mahasiswa yang dipengaruhi oleh angkatan kuliah. Mahasiswa angkatan 2015 cenderung masuk kategori stres rendah dengan sebaran 50,0\%, Sementara mahasiswa angkatan 2016, 2017, dan 2018 cenderung masuk kategori stres sedang dengan sebaran diatas $55 \%$.

Tabel 16 Uji beda stres dan status kerja

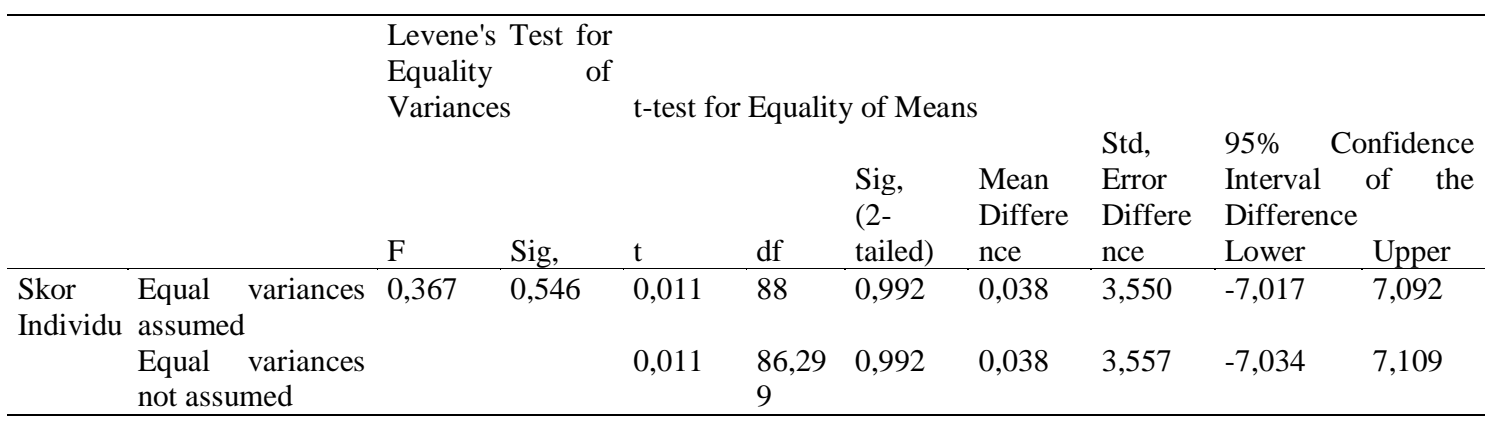

Dilihat dari tabel diatas bahwa nilai signifikansi antara stres dan status kerja adalah 0,992 (lebih besar dari 0,05), dengan demikian dapat disimpulkan bahwa tingkat stres mahasiswa TI UBP Karawang tidak ada perbedaan karena status kerja.

Uji korelasi dipakai untuk mengetahui hubungan antara satu variabel dengan variabel yang lain. Dalam penelitian ini ada 4 (empat) pengujian korelasi yang dilakukan.

Tabel 17 Uji korelasi tingkat stres dengan jenis kelamin

\begin{tabular}{llrr}
\hline & & Tingkat Stres & Jenis Kelamin \\
\hline Tingkat Stres & Pearson Correlation & 1 & 0,071 \\
& Sig, (2-tailed) & & 0,505 \\
& N & 90 & 90 \\
Jenis Kelamin & Pearson Correlation & 0,071 & 1 \\
& Sig, (2-tailed) & 0,505 & \\
& N & 90 & 90 \\
\hline
\end{tabular}

Hasil uji korelasi diperoleh nilai signifikansi sebesar 0,505 dan koefisien korelasi sebesar 0,071. Hasil ini menunjukan bahwa tidak ada korelasi (hubungan) yang berarti antara tingkat stres dengan jenis kelamin.

Tabel 18 Uji korelasi tingkat stres dengan usia responden

\begin{tabular}{llrr}
\hline & & Tingkat Stres & Usia Responden \\
\hline Tingkat Stres & Pearson Correlation & 1 & 0,012 \\
& Sig, (2-tailed) & & 0,910 \\
& N & 90 & 90 \\
Usia Responden & Pearson Correlation & 0,012 & 1 \\
& Sig, (2-tailed) & 0,910 & 90 \\
& N & 90 & 90 \\
\hline
\end{tabular}

Dari data diatas diperoleh nilai signifikansi sebesar 0,910 dan koefisien korelasi sebesar 0,012. Hasil ini menunjukan bahwa tidak ada korelasi (hubungan) yang berarti antara tingkat stres dengan usia responden (mahasiswa). 
Tabel 19 Uji korelasi tingkat stres dengan angkatan kuliah

\begin{tabular}{|c|c|c|c|c|}
\hline & & & Tingkat Stres & Angkatan \\
\hline \multirow{6}{*}{$\begin{array}{l}\text { Spearman's } \\
\text { rho }\end{array}$} & Tingkat Stres & Correlation Coefficient & 1,000 & $-0,100$ \\
\hline & & Sig, (2-tailed) & & 0,346 \\
\hline & & $\mathrm{N}$ & 90 & 90 \\
\hline & Angkatan & Correlation Coefficient & $-0,100$ & 1,000 \\
\hline & & Sig, (2-tailed) & 0,346 & \\
\hline & & $\mathrm{N}$ & 90 & 90 \\
\hline
\end{tabular}

Dari data diatas diperoleh nilai signifikansi sebesar 0,346 dan koefisien korelasi sebesar 0,100. Hasil ini menunjukan bahwa tidak ada korelasi (hubungan) yang berarti antara tingkat stres dengan angkatan kuliah.

Tabel 20 Uji korelasi tingkat stres dengan status kerja

\begin{tabular}{llrr}
\hline & & Tingkat Stres & Status Kerja \\
\hline Tingkat Stres & Pearson Correlation & 1 & $-0,001$ \\
& Sig, (2-tailed) & & 0,992 \\
Status Kerja & N & 90 & 90 \\
& Pearson Correlation & $-0,001$ & 1 \\
& Sig, (2-tailed) & 0,992 & 90 \\
\hline
\end{tabular}

Dari data diatas diperoleh nilai signifikansi sebesar 0,992 dan koefisien korelasi sebesar 0,001. Hasil ini menunjukan bahwa tidak ada korelasi (hubungan) yang berarti antara tingkat stres dengan status kerja mahasiswa.

\section{Conclusion}

Berdasarkan pembahasan diatas, kesimpulan dari penelitian ini:

1. Terdapat perbedaan tingkat stres mahasiswa TI UBP Karawang untuk angkatan 2015, 2016, 2017 dan 2018 yang diukur dengan metode skoring dari Health and Safety Executive (HSE), hasilnya mahasiswa angkatan 2015 cenderung memiliki tingkat stres rendah dibandingkan dengan 3 angkatan lainnya yang cenderung memiliki tingkat stres sedang. Hal ini terjadi karena mahasiswa 2015 sudah memasuki semester akhir, sudah tidak ada perkuliahan, hanya menyelesaikan dan menunggu sidang Tugas Akhir, sehingga tidak lagi mengalami tingkat stres yang berlebih. Sementara mahasiswa angkatan 2016 kategori stres tinggi sebesar 33,3\% lebih besar dari 3 angkatan lainnya, hal ini kemungkinan terjadi karena mahasiswa 2016 akan menghadapi Tugas Akhir.

2. Jenis kelamin, Usia, Status Kerja TIDAK mempengaruhi tingkat stres mahasiswa TI UBP Karawang.

3. Dari keempat uji korelasi yang dilakukan TIDAK ADA ada hubungan yang berarti antara jenis kelamin, usia, angkatan kuliah dan status kerja dengan tingkat stres mahasiswa.

\section{References}

[1] Abdulghani, H.M., dkk., Stres and its Effects on Medical Students, a Cross-Sectional Study at a College of Medicine in Saudi Arabia, Journal of Health, Population and Nutrition, 29(5): 516-522.2011

[2] Anfas, dkk.,Pengukuran Tingkat Stres Mahasiswa Berdasarkan Gender, Aplikasi Importance Perfornace Analysis, Jurnal Pendidikan Terbuka dan Jarak Jauh, 19(1): 38-51.2018

[3] Augesti, G., dkk. Differences in Stres Level Between First Year and Last Year Medical Students in Medical Faculty of Lampung University, Medical Journal of Lampung University, 4(4): 50-56.2015

[4] Dewi, H., dkk.Psikologi Industri dalam Perspektif Sistem Industri, UB Pres, Malang.2017 
[5] Hardjana, A.M.,Stres Tanpa Distres: Seni Mengolah Stres, Kanisius, Yogyakarta.1994

[6] Legiran, dkk., Faktor Risiko Stres dan Perbedaannya pada Mahasiswa Berbagai Angkatan di Fakultas Kedokteran Universitas Muhammadiyah Palembang, Jurnal Kedokteran dan Kesehatan, 2(2): 197-202.

[7] Manuaba, A.S. Stres and Strain, Dalam: Bunga Rampai Ergonomi Vol I, Program Studi Ergonomin - Fisiologi Kerja Universitas Udayana Denpasar, Bali.1998

[8] Maulana, Z.F., dkk., Differences in Stres Level Between First-Year and Second-Year Meducal Student in Medical Faculty of Lampung University, Medical Journal of Lampung University, 3(4): 154-162.2014

[9] Oktovia, W, dkk, Hubungan Kecerdasan Emosional dengan Tingkat Stres pada Mahasiswa Tahun Pertama Fakultas Kedokteran Universitas Riau, (https://repository,unri,ac,id/bitstream/handle/123456789/2229/REPOSITORI\%20WIRA\% 20OKTOVIA\%200908120342,pdf, diakses pada tanggal 24 Pebruari 2019),

[10] Olpin, M. dan Hesson, M., Stres management for life: a research-based experiental approach, Wadsworth Cengage Learning, 2nd edition, USA.2009 